\title{
Construction professionals' environmental perceptions of lumber, concrete and steel in Japan and China
}

\author{
by Daisuke Sasatani ${ }^{1}$ and Ivan Eastin ${ }^{2}$
}

\begin{abstract}
As green building programs (GBPs) are introduced in Asian countries, the question of how GBPs evaluate the "greenness" of construction practice becomes one of the most critical uncertainties for the building material industry. To better understand construction professionals' perception of greenness and the greenness of different building materials in Japan and China, surveys were conducted in both countries in 2009 and 2010. The surveys were designed to evaluate professionals' perceptions of the relative importance of the major environmental attributes of resource efficiency. Chinese and Japanese professionals ranked the environmental attributes similarly even though their construction practices are very different. They perceive that saving energy and saving water are substantially more important environmental attributes than using renewable materials, having a low carbon footprint and using recycled materials. Second, the survey was designed to gain insights into the respondents' perceptions of the relative environmental performance of the three major structural building materials (wood, concrete and steel). In both countries, construction professionals perceive lumber as having the best environmental performance relative to concrete and steel. However, Chinese and Japanese professionals have different perceptions of lumber in terms of its environmental friendliness. In Japan, energy efficiency of houses, the level of pollution generated during the manufacturing process, and $\mathrm{CO}_{2}$ emissions contribute to the evaluation of the environmental friendliness of lumber. In China, the sustainability of the resource is the main factor perceived as promoting the environmental friendliness of lumber.
\end{abstract}

Key words: green building programs, environmental perceptions, sustainability, environmental performance, Chinese builders, Japanese builders

\section{RÉSUMÉ}

Avec l'introduction des programmes d'immeubles verts (PIV) dans les pays asiatiques, la question de lévaluation par les PIV de la « verdeur » des pratiques de construction est devenue l'une des principales incertitudes pour l'industrie des matériaux de construction. Afin de mieux comprendre comment les professionnels de la construction perçoivent la notion de verdeur et la verdeur des différents matériaux de construction au Japon et en Chine, des sondages ont été effectués dans les deux pays en 2009 et en 2010. Les sondages ont été conçus pour évaluer les perceptions des professionnels de l'importance relative des principales qualités environnementales de l'utilisation efficiente des ressources. Les professionnels chinois et japonais ont classé de façon similaire les qualités environnementales même si leurs pratiques de construction sont très différentes. Ils considèrent que les économies d’énergie et d'eau constituent des qualités environnementales substantiellement plus importantes que l'utilisation de matériaux recyclables, de matériaux à faible empreinte environnementale et de matériaux recyclés. De plus, le sondage a été développé pour établir les répondants voient la performance environnementale relative de trois des trois principaux matériaux utilisés dans les structures d'immeuble (le bois, le béton et l'acier). Dans les deux pays, les professionnels de la construction perçoivent le bois comme ayant la meilleure performance environnementale comparativement au béton et à l'acier. Cependant, les professionnels chinois et japonais ont des perceptions différentes au niveau de ses qualités environnementales. Au Japon, lefficacité énergétique des immeubles, le niveau de pollution généré au cours de processus de fabrication et les émissions de $\mathrm{CO}_{2}$ font partie de lévaluation de la qualité environnementale du bois. En Chine, la durabilité de la ressource représente le principal facteur perçu comme étant le promoteur de la qualité environnementale du bois.

Mots clés : programmes d'immeubles verts, perceptions environnementales, durabilité, performance environnementale, constructeurs chinois, constructeurs japonais

\footnotetext{
${ }^{1}$ Research Assistant, Center for International Trade in Forest Products (CINTRAFOR), School of Forest Resources, Box 352100, University of Washington, Seattle, WA 98195-2100, USA. E-mail: sasatani@uw.edu

${ }^{2}$ Director and Professor, Center for International Trade in Forest Products (CINTRAFOR), School of Forest Resources, Box 352100, University of Washington, Seattle, WA 98195-2100, USA. E-mail: eastin@uw.edu
} 


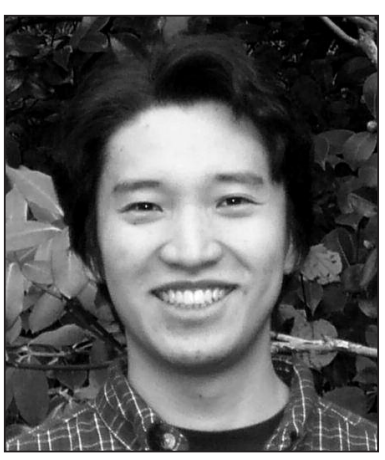

Daisuke Sasatan

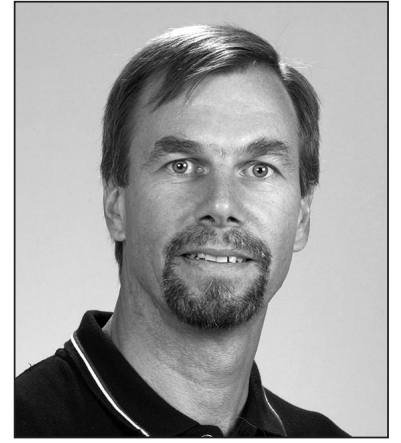

Ivan Eastin

\section{Introduction}

Green building is the practice of constructing "green" buildings, creating and utilizing healthier and more resource-efficient methods of construction, renovation, operation, maintenance and demolition (USGBC 2011, EPA 2010). In order to promote "green" buildings, industrial associations and/or government have created Green Building Programs (GBPs) designed to promote the use of more sustainable products and systems for residential and non-residential buildings. Generally, the goal of GBPs is to reduce the impacts of new and renovated buildings on the environment and human health by improving energy efficiency, reducing water use, enhancing material efficiency, reducing waste generation, and improving indoor environmental air quality (EPA 2010). GBPs are popular in a number of European countries and in North America, but they have only recently been introduced in Asian countries, including Japan and China. For example, Japan recently introduced the Comprehensive Assessment of Systems for Building Environmental Efficiency (CASBEE) green building program. The CASBEE GBP is a voluntary program that was jointly developed by the residential construction industry and the Ministry of Land, Infrastructure and Transportation (Eastin 2008). Similarly, China has established its national GBP, the Chinese Evaluation Standard for Green Building, also known as the Three Star System (Eastin et al. 2011).

Most GBPs are designed and organized into guidelines that are accompanied by a checklist and/or a points system. Typically, GBP guidelines are divided into sections such as energy usage, water usage, material usage, indoor air quality, and site development and selection. Points are awarded for incorporating designs, products and technologies that improve the environmental performance of the structure and reduce waste (e.g., JSBC 2008, USGBC 2011). Usually, builders and architects who use GBPs on a routine basis are most interested in using the simplest possible index for assessing the environmental performance of a house because it is easier for them to use. However, considering GBPs from a scientific perspective, it is not always possible to objectively integrate and quantify the importance of multi-dimensional environmental attributes. To improve the usability of a GBP, some subjective weighting methods are often employed to aggregate the environmental attributes (Kuosmanen and Kortelainen 2005). In this way, a GBP's methodology can assess the "greenness" of different building materials and thereby influ- ence the material choices of construction professionals. For example, if wood is officially assessed to be a "green" building material within a GBP, the share of wood used within that market could be expected to increase.

Without support from construction professionals, GBPs cannot be expected to meet their goals. Since construction professionals, both builders and architects, are responsible for specifying building materials, it is critically important that we understand how these individuals perceive the relative importance of different environmental attributes, how these attributes influence their material selection decisions and how they perceive the relative environmental performance of competing building materials. If the system employed within a GBP to evaluate and assess the environmental performance of building materials conflicts with end-users' perceptions, they will be less likely to try and adopt the GBP. However, individuals always hold different opinions regarding the relative importance of the various attributes that are contained within a GBP. To a large degree, these different opinions are influenced by an end-users' cultural background or professional biases. This study attempts to assess the environmental perceptions of building professionals in China and Japan in an effort to understand how they evaluate the environmental performance of different building materials and their perceptions of the complex combination of material and performance attributes that make up GBPs.

\section{Methodology}

To better understand the environmental perceptions of construction professionals in Japan and China, researchers at CINTRAFOR at the University of Washington conducted a series of surveys in 2009 and 2010 at several representative builder trade shows. We collected a total of 837 completed surveys from both Japan and China. In Japan, 530 surveys were collected during the 2009 Tokyo Home Show, the 2010 Tokyo Architecture Show and during two building material trade missions sponsored by the State of Washington in 2009. A total of 307 surveys was also collected in China during the US-China Build trade missions held in September 2009 (in Hangzhou, Wuhan and Qingdao) and May of 2010 (in Guangzhou and Shanghai).

The surveys were designed to understand respondents' overall perceptions of resource efficiency in construction applications and to assess their perceptions of the environmental performance of wood relative to concrete and steel in structural end-use applications. The surveys were developed in English based on preliminary interviews with GBP experts in Japan and in China. The surveys were then translated into both Japanese and Chinese by CINTRAFOR graduate students from each country. They were then translated back into English in an effort to cross-check the quality of the translation.

One set of survey questions was designed to assess professionals' perceptions of the relative importance of five important attributes related to environmental performance and resource efficiency. Survey respondents rated the importance of these environmental attributes in influencing their material purchasing decisions using a five-point Likert-like scale where a rating of 1 meant "not important" and a rating of 5 meant "very important". The environmental attributes specified in the surveys were; 1) energy efficient materials and 
products, 2) renewable materials, 3) water-saving appliances and fixtures, 4) recycled materials, and 5) materials that have a low carbon footprint.

When conducting cross-cultural research, it is important to determine whether the scores obtained from individuals in one country are comparable to those obtained from respondents in the second country. In order to remove individual and/or cross-cultural bias, a standardization technique is often utilized (e.g., Hofstede 1980, Leung and Bond 1989, Schwartz et al. 2001). In this study it was assumed that while an individual respondent can compare the relative importance of the five environmental attributes, the magnitude of importance specified within the survey may be difficult for the respondent to interpret since there is not an absolute reference point and therefore there is a possibility that responses can be biased by inter-personal and cross-cultural influences.

A thorough review of the completed surveys found that some respondents did not differentiate their answers and simply selected the same level of importance for each of the environmental attributes. While it is possible that some of these respondents perceived no difference between the individual attributes, others may have simply been looking to complete the survey quickly. In order to better differentiate respondents' individual importance ratings, a within-subject standardized score (with a unit of sigma) was calculated for each environmental attribute. In this way, we can focus on the perceived differences of each respondent regarding the five environmental attributes. While the scores computed by this within-subject standardization procedure may not be statistically independent of one another, and this ipsative score limits the subsequent statistical analysis (especially the use of correlation analysis and factor analysis [Fischer 2004]), it is an ideal way to describe the individual's relative psychological distances among the five environmental attributes.

A second set of questions on the survey looked at how respondents in each country assessed the relative environmental performance of wood relative to steel and concrete used in structural applications. The five environmental performance measures (independent variables) used in the study included; 1) energy consumption during the production of each building material, 2) the sustainability of each building material 3) the amount of pollution generated during the production of each building material, 4) the energy efficiency of a house built using each building material and 5) the amount of $\mathrm{CO}_{2}$ emissions generated during the production of each raw material. We also asked each respondent to rate the overall environmental friendliness of each building material (dependent variable). The environmental performance of each building material was rated using a scale where " $1=$ low environmental performance", " $2=$ medium" and " $3=$ high environmental performance". Each respondent's rating for wood was compared to their evaluation for steel and concrete and a standardized score was calculated for each environmental category. The results were evaluated using an M-estimation technique of robust regression (Huber 1964) to include all independent variables, country dummy variable, and the interaction between independent variables and country dummy variable to see which environmental categories contribute to the overall environmental friendliness of lumber compared to steel and concrete. In cases where the error distribution was not normal, ordinal least square (OLS) esti- mates can behave badly, although robust regression analysis is not as vulnerable to deviations from normality.

\section{Results}

\section{Perception of environmental attributes}

The standardized scores of the Chinese and Japanese respondents for the five environmental attributes for resource efficiency are shown in violin plots (Fig. 1). A violin plot is a combination of a box-and-whisker plot and a kernel density plot, so it is similar to a box plot but it also shows the estimated probability density of the data (Hintze and Nelson 1998).

In China, energy efficiency of the home was perceived to be the most important environmental attribute with a sample mean score of 0.34 sigma, the only attribute with a mean that was significantly higher than zero. Using renewable raw materials and saving water were not perceived as being important attributes. Finally, reduced $\mathrm{CO}_{2}$ emissions and using recycled materials were both perceived as having a significantly negative importance rating.

In Japan, energy efficiency of the home and water-saving were both perceived to be significantly important environmental attributes by survey respondents. In contrast, the remaining three attributes, renewable materials, recycled materials and reduced $\mathrm{CO}_{2}$ emissions, were all perceived as having a significantly negative importance rating.

Due to the possibility of cross-cultural bias and the standardization process used, we will not directly compare the mean standard score between Chinese and Japanese, but the overall ranking of the two most significant attributes, energy efficiency and recycled materials, were rated similar by respondents in both countries.

\section{Perceptions of the relative environmental performance of build- ing materials}

The mean score and standard deviations of the standardized environmental perception attribute rating scores for survey respondents in both countries are displayed in Table 1. A significantly large attribute rating score (greater than zero) means that the material is perceived as being better for the environment than are lower-rated materials. An attribute rating score close to zero means that a material is perceived as being neutral in terms of its environmental performance while a negative environmental rating means that the material is perceived as being low in terms of its environmental performance.

The perceived environmental friendliness (dependent variable) of wood was rated at 0.916 in Japan and 0.632 in China, a score that is significantly higher than that of either concrete or steel (and this is true for respondents in both countries). Respondents from both countries overwhelmingly perceived that wood exhibited a superior environmental performance relative to steel and concrete across each of the environmental attributes. The results for wood were found to be significantly better than for either steel or concrete in every case for the Japanese respondents and in virtually every instance for the Chinese respondents, although the Japanese respondents tended to rate wood substantially higher than their Chinese counterparts (with the exception of "overall sustainability"). This result is not unexpected since the Japanese have a long history of building their homes from 


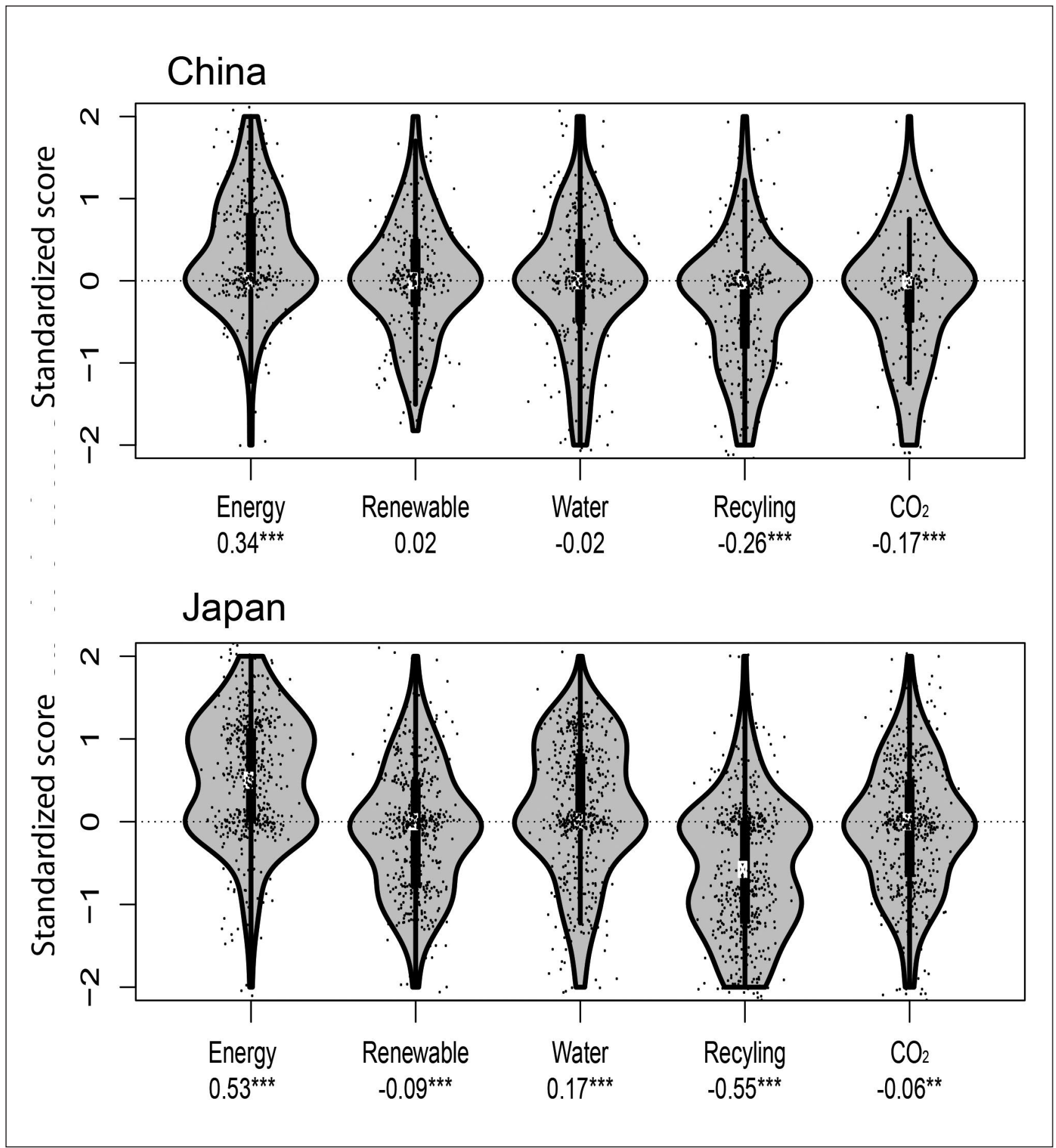

Fig. 1. Violin plot of comparative score ratings for the five environmental attributes in China and Japan.

Dots on violin plots represent the individual responses. Due to prevent overplotting, dots are jittered.

$* \%$ and $* \%$ represent $1 \%$ and $5 \%$ significance, respectively, by applying one sample t-test on whether the mean value is different from 0 or not.

wood (even today approximately $45 \%$ of Japanese homes are built from wood). What is interesting is that despite the fact that there are very few homes built from wood in China, wood was still perceived as being environmentally superior to both steel and concrete.

Respondent's ratings for the "overall sustainability" attribute were a bit more ambiguous, although the majority of respondents from both countries perceived that wood had the highest level of sustainability and concrete had the lowest level of sustainability. It should be noted that when administering the survey, we allowed respondents to decide what the term "sustainability" meant to them, which means that each respondent may have applied a different definition for the term. In considering the attribute "energy efficiency of com- 
Table 1. Respondents' perceptions of the relative environmental performance for wood, concrete and steel in Japan and China

\begin{tabular}{|c|c|c|c|c|c|c|}
\hline & Lumber & $\begin{array}{l}\text { Japan } \\
\text { Concrete }\end{array}$ & Steel & $\begin{array}{l}\text { China } \\
\text { Lumber }\end{array}$ & Concrete & Steel \\
\hline $\begin{array}{l}\text { Overall environmental } \\
\text { friendliness (dependent variable) }\end{array}$ & $\begin{array}{l}\mathbf{0 . 9 1 6} \\
(0.74)\end{array}$ & $\begin{array}{c}-0.448^{\star * *} \\
(0.54)\end{array}$ & $\begin{array}{l}-0.471^{\star * *} \\
(0.58)\end{array}$ & $\begin{array}{c}\mathbf{0 . 6 3 2 * * *} \\
(0.98)\end{array}$ & $\begin{array}{c}-0.370^{\star * *} \\
(0.70)\end{array}$ & $\begin{array}{l}-0.285^{\star * *} \\
(0.84)\end{array}$ \\
\hline Energy consumption during manufacturing & $\begin{array}{c}\mathbf{0 . 8 7 1} \mathbf{1}^{\star * *} \\
(0.76)\end{array}$ & $\begin{array}{l}-0.218^{\star * *} \\
(0.59)\end{array}$ & $\begin{array}{c}-0.653^{* * *} \\
(0.64)\end{array}$ & $\begin{array}{c}\mathbf{0 . 5 3 1} 1^{\star * *} \\
(1.05)\end{array}$ & $\begin{array}{l}-0.046 \\
(0.69)\end{array}$ & $\begin{array}{c}-0.489^{* * *} \\
(0.85)\end{array}$ \\
\hline Sustainability & $\begin{array}{c}\mathbf{0 . 1 9 0}^{* * *} \\
(0.99)\end{array}$ & $\begin{array}{l}-0.181^{* * *} \\
(0.69)\end{array}$ & $\begin{array}{l}-0.010 \\
(0.74)\end{array}$ & 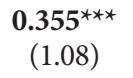 & $\begin{array}{l}-0.349^{* * *} \\
(0.86)\end{array}$ & $\begin{array}{l}-0.004 \\
(0.78)\end{array}$ \\
\hline Pollution emission during manufacturing & $\begin{array}{c}\mathbf{0 . 9 1 4} 4^{* * *} \\
(0.69)\end{array}$ & $\begin{array}{c}-0.326^{* * *} \\
(0.59)\end{array}$ & $\begin{array}{c}-0.594^{* * *} \\
(0.62)\end{array}$ & $\begin{array}{c}\mathbf{0 . 7 3 2}^{\star * *} \\
(0.97)\end{array}$ & $\begin{array}{l}-0.354^{* * *} \\
(0.71)\end{array}$ & $\begin{array}{c}-0.378^{* * *} \\
(0.78)\end{array}$ \\
\hline Energy efficiency of completed house & $\begin{array}{l}\mathbf{0 . 5 6 5} \mathbf{5}^{\star * *} \\
(0.89)\end{array}$ & $\begin{array}{l}-0.093^{\star * *} \\
(0.73)\end{array}$ & $\begin{array}{c}-0.474^{\star * *} \\
(0.64)\end{array}$ & $\begin{array}{c}\mathbf{0 . 3 9 2} \\
(1.06)\end{array}$ & $\begin{array}{l}-0.155^{\star * \star} \\
(0.73)\end{array}$ & $\begin{array}{c}-0.236^{\star * *} \\
(0.89)\end{array}$ \\
\hline $\begin{array}{l}\mathrm{CO}_{2} \text { emission during manufacturing } \\
\text { and transportation }\end{array}$ & $\begin{array}{c}\mathbf{0 . 7 9 3}^{* * *} \\
(0.75)\end{array}$ & $\begin{array}{l}-0.236^{* * *} \\
(0.57)\end{array}$ & $\begin{array}{l}-0.555^{* * *} \\
(0.60)\end{array}$ & $\begin{array}{c}\mathbf{0 . 4 3 4} 4^{\star * *} \\
(1.03)\end{array}$ & $\begin{array}{c}-0.084^{*} \\
(0.66)\end{array}$ & $\begin{array}{c}-0.352^{* * *} \\
(0.87)\end{array}$ \\
\hline
\end{tabular}

Mean value with (standard deviation) of within-attribute standardized score.

Bold figure represents the highest score among three materials in each attribute.

${ }^{*},{ }^{* *},{ }^{* *}$ mean $10 \%, 5 \%, 1 \%$ significance to reject the null hypothesis that the mean value is equal to 0 .

Table 2. Results of robust regression for the relative environmental friendliness of lumber

\begin{tabular}{|c|c|c|c|c|c|c|c|c|c|c|c|c|}
\hline & \multicolumn{3}{|c|}{ M1: Overall } & \multicolumn{3}{|c|}{ M2: Full } & \multicolumn{3}{|c|}{ M3: Japan only } & \multicolumn{3}{|c|}{ M4: China only } \\
\hline & P.E. & S.E. & & P.E. & S.E. & & P.E. & S.E. & & P.E. & S.E. & \\
\hline Intercept & 0.62 & 0.04 & $* * *$ & 0.55 & 0.05 & $* * *$ & 0.55 & 0.05 & $* * *$ & - & - & - \\
\hline Energy consumption & -0.02 & 0.04 & - & 0.04 & 0.04 & - & 0.04 & 0.04 & - & - & - & - \\
\hline Sustainability & 0.08 & 0.03 & $* * *$ & 0.01 & 0.03 & - & 0.01 & 0.03 & - & - & - & - \\
\hline Pollution & 0.16 & 0.04 & $* *$ & 0.23 & 0.05 & $* * *$ & 0.23 & 0.04 & $* * *$ & - & - & - \\
\hline Energy efficiency & 0.27 & 0.03 & $* * *$ & 0.24 & 0.03 & $* * *$ & 0.24 & 0.03 & $* * *$ & - & - & - \\
\hline $\mathrm{CO}_{2}$ & 0.06 & 0.04 & - & 0.10 & 0.04 & $\star *$ & 0.10 & 0.04 & $* *$ & - & - & - \\
\hline China Dummy & & & - & -0.21 & 0.08 & $* *$ & - & - & - & 0.34 & 0.08 & $* * *$ \\
\hline $\begin{array}{l}\text { China } \times \text { Energy } \\
\text { consumption }\end{array}$ & - & - & - & -0.10 & 0.08 & - & - & - & - & -0.05 & 0.09 & - \\
\hline China $\times$ Sustainability & - & - & - & 0.61 & 0.07 & $* * *$ & - & - & - & 0.63 & 0.08 & $* * *$ \\
\hline China $\times$ Pollution & - & - & - & -0.25 & 0.10 & $* *$ & - & - & - & -0.02 & 0.11 & - \\
\hline China $\times$ Energy efficienc & cy- & - & - & -0.14 & 0.07 & * & - & - & - & 0.10 & 0.08 & - \\
\hline China $\times \mathrm{CO}_{2}$ & - & - & - & 0.02 & 0.09 & & - & - & - & 0.12 & 0.10 & - \\
\hline Deviance & & 311.1 & & & 290.1 & & & $208.0^{\mathrm{a}}$ & & & $82.5^{\mathrm{b}}$ & \\
\hline AIC & & 1304.7 & & & 1275.8 & & & $956.5^{\mathrm{a}}$ & & & $313.9^{\mathrm{b}}$ & \\
\hline $\mathrm{BIC}$ & & 1335.3 & & & 1332.6 & & & $985.4^{\mathrm{a}}$ & & & $333.6^{\mathrm{b}}$ & \\
\hline
\end{tabular}

${ }^{*}, * *, * *$ represent $10 \%, 5 \%$ and $1 \%$ significance, respectively.

a and ${ }^{b}$ : Since sample size is different, these indicators are not comparable to other models.

pleted house", we see that the Japanese professionals rated the wood-framed house significantly higher $(+0.565)$ than either a concrete $(-0.093)$ or a steel-framed house $(-0.474)$. It is interesting that this same ranking was also provided by the Chinese respondents, even though most of them have little practical experience in either building or living in a woodframed house.

These results clearly show that wood is perceived by building professionals in both China and Japan as providing superior environmental performance relative to steel and concrete across all five of the environmental attributes that were evaluated. Respondents were much more ambiguous regarding the relative environmental performance of steel and concrete with respect to both the environmental attributes as well as the country location of the respondent and no universal conclusion could be determined in this case.

\section{Regression analysis of environmental friendliness of lumber} In conducting the regression analysis, those respondents who did not provide a response to the question asking about the 
Table 3. Summary of regression results for the relative environmental friendliness of wood

\begin{tabular}{lll}
\hline & Japan & China \\
\hline Reduced energy consumption during manufacturing & n.s. & n.s. \\
Reduced pollution emissions during manufacturing & $\uparrow_{* *}$ & n.s. \\
Reduced $\mathrm{CO}_{2}$ emissions during manufacturing & $\uparrow *$ & n.s. \\
Increased energy efficiency of the completed house & $\uparrow_{* *}$ & n.s. \\
Overall sustainability of the material is higher & n.s. & $\uparrow_{* *}$ \\
\hline
\end{tabular}

${ }^{* *}$ significant at the .01 level; ${ }^{*}$ significant at the .05 level

"overall environmental friendliness" of each building material (the dependent variable) were removed from the database prior to the analysis. As a result, the sample size for the regression analysis was 635 (477 from Japan and 158 from China).

The results of the robust regression model are provided in Table 2. The overall model (M1) utilizes the entire dataset and does not differentiate between Japanese and Chinese respondents. The full model (M2) includes the full dataset but it also has a country dummy variable and all interaction terms. The Japan only model (M3) and the China only model (M4) only include respondent data from each country. Since M2 has lower AIC and BIC values than does M1 and by applying the likelihood-ratio test on $\mathrm{M} 1$ and $\mathrm{M} 2, \mathrm{D}=40.89$ with $d . f .=6$ ( $p$ $<0.001)$, M2 appears to be a better model than does the nested M1. This result strongly suggests that there are quantifiable country effects between the Japanese respondents and the Chinese respondents.

Since M2 was determined to be the best model, it will provide the basis for the following discussion. The intercept of the Japanese data is 0.55 whereas the intercept for the Chinese respondent data is substantially lower at 0.21 . The difference between the intercept values for the two countries is significant at the $1 \%$ level, suggesting that the perceived environmental friendliness of wood relative to concrete and steel is significantly higher for Japanese construction professionals than it is for Chinese construction professionals (holding the other dependent variables constant).

The coefficient for the variable "energy consumption during manufacturing" for both the Japanese and Chinese construction professionals was not significantly different from 0 , suggesting that the amount of energy consumed during the manufacturing process for each of the materials does not appear to influence respondent's perception of the overall environmental friendliness of wood relative to steel and concrete in either country.

The coefficient for the variable "sustainability of wood" was not significantly different from zero for the Japanese respondents, suggesting that it does not influence respondent's perception of the overall environmental friendliness of wood relative to steel and concrete. However, the coefficient for the sustainability variable for the Chinese construction professionals was 0.61 higher than that of the Japanese professionals (significant at the $1 \%$ level). This result suggests that Chinese construction professionals perceive that the overall sustainability of wood is an important factor in differentiating between the environmental friendliness of wood relative to steel and concrete.

The coefficients for the variables "pollution emission during the manufacturing process" and "energy efficiency of the completed house" were 0.23 and 0.24 , respectively, for the Japanese data. Both of these values were highly significant at the $1 \%$ level. In contrast, the coefficients for these variables for the Chinese data were 0.02 and 0.10 , significantly lower than the coefficients for the Japanese data and not significantly different from zero. These results indicate that Japanese construction professionals (but not their Chinese counterparts) perceive that wood is a more environmentally friendly building material than either steel or concrete because it emits less pollution during the manufacturing process and also because wood-framed houses are perceived to be more energy-efficient.

Finally, the coefficient for the variable " $\mathrm{CO}_{2}$ emission during the manufacturing and transportation of wood materials" in Japan was 0.10 (significant at the $5 \%$ level). While the magnitude of the coefficient is less than half that observed for the "pollution emission" and "energy efficiency" variables, Japanese construction professionals still perceive that the reduced $\mathrm{CO}_{2}$ emissions for wood during the manufacturing process makes wood a more environmentally friendly material than either steel or concrete. In contrast, the results from the Chinese data suggest that this variable was not significant in differentiating between materials.

\section{Discussion}

Both in Japan and in China, the ranking of the importance among five resource-efficiency attributes show fairly similar results. In both countries, building professionals perceive that using energy-efficient materials and products is the most important among five attributes. Using water-saving appliances and fixtures received a much lower overall score relative to the energy efficiency category, although it was still perceived as being the second-most important attribute in both countries (but was not significantly different from zero with the China data). It appears that respondents tended to rate those attributes that most directly impact the operating efficiency of a house significantly higher than the other attributes. This could be due to a policy emphasis in each country to improve the operating efficiency of new houses or it could be attributed to companies using operating efficiency as a marketing strategy to differentiate their homes in the marketplace. In contrast, the resource-efficiency attributes (using renewable materials, using recycled materials and reduced $\mathrm{CO}_{2}$ emissions) were rated as being significantly less important.

This research also found that construction professionals in both countries perceive wood to be a more environmentally friendly building material than either steel or concrete, although the rationale for this appears to be different in the two countries. Both energy consumption during the manufacturing process and overall sustainability of the material 
were not perceived by Japanese respondents as being significantly different between the three materials.

Unlike in Japan and North America where detached, single-family homes make up a significant proportion of the housing markets, medium- and high-rise apartments and condominiums are the dominant types of residential housing in China. Almost all residential housing in China is built from reinforced concrete and bricks, a fact that has restricted the adoption and diffusion of wood-framed construction technology in China. Despite this, the results of this research suggest that Chinese construction professionals perceive that wood is environmentally superior to both steel and concrete. However, green building programs based on the environmental performance of building materials and the related social concerns of sustainability have not been widely accepted by construction professionals in China (Chan et al. 2009).

Green building programs will increasingly influence construction professionals' perceptions of environmental friendliness as well as the types of building materials that they specify for residential housing in Japan and China. This study only focused on the psychological perception of environmental friendliness within construction professionals in China and Japan. The results suggest that wood is perceived as being more environmental friendly than either concrete or steel in both countries. The results also show that the energy efficiency of a house is rated as being one of the most important environmental attributes by construction professionals in both countries and that construction professionals in both Japan and in China perceive that wood-framed houses are more energy-efficient than either steel or concrete homes. While green building programs represent a good opportunity to expand wood use in Japan and in China, these research results suggest that it is important to educate Japanese and Chinese construction professionals and policy-makers about the superior environmental performance of wood building materials relative to steel and concrete.

\section{Acknowledgements}

We thank Dr. Indroneil Ganguly (CINTRAFOR) for his excellent research assistance. This research was supported by travel support from the USDA Foreign Agricultural Service, the Evergreen Building Products Association and FPInnovations.

\section{References}

Chan, E.H.W., Q.K. Qian and P.T.I. Lam. 2009. The market for green building in developed Asian cities - the perspectives of building designers. Energy Policy 37(8): 3061-3070.

Eastin, I.L. 2008. Review of the Japanese green building program and the domestic wood program. Working paper 111, CINTRAFOR, University of Washington, Seattle, WA.

Eastin, I.L., D. Sasatani, I. Ganguly, J.X. Cao and M. Seol. 2011. The impact of green building programs on the Japanese and Chinese residential construction industries and the market for imported wooden building materials. Working paper 121, CINTRAFOR, University of Washington, Seattle, WA.

[EPA] US Environmental Protection Agency. 2010. Green Building: Basic Information [online]. Available at http://www.epa. gov/greenbuilding/pubs/about.htm [Accessed 3 June 2012].

Fischer, R. 2004. Standardization to Account for Cross-cultural Response Bias: A Classification of Score Adjustment Procedures and Review of Research in JCCP. Journal of Cross-Cultural Psychology 35(3): 263-82.

Hofstede, G. 1980. Culture's consequences: International studies of work-related values. Sage, Newbury Park, CA

Hintze, J.L. and R.D. Nelson. 1998. Violin Plots: A Box Plot-Density Trace Synergism. The American Statistician 52(2): 181-184.

Huber, P.J. 1964. Robust estimation of a location parameter. The Annals of Mathematical Statistics 35(1): 73-101.

[JSBC] Japan Sustainable Building Consortium. 2008. The assessment method employed by CASBEE [online]. Available at http://www.ibec.or.jp/CASBEE/english/methodE.htm [Accessed 3 June 2012].

Kuosmanen, T. and M. Kortelainen. 2005. Measuring eco-efficiency of production with data envelopment analysis. Journal of Industrial Ecology 9(4): 59-72.

Leung, K., and M.H. Bond. 1989. On the empirical identification of dimensions for cross-cultural comparison. Journal of Cross-Cultural Psychology 2(2): 133-151.

Schwartz, S.H., G. Melech, A. Lehmann, S. Burgess, M. Harris and V. Owens. 2001. Extending the cross-cultural validity of the theory of basic human values with a different method of measurement. Journal of Cross-Cultural Psychology 32(5): 519-542.

[USGBC] US Green Building Council. 2011. What LEED is [online]. Available at http://www.usgbc.org/DisplayPage.aspx?CMS PageID=1988 [Accessed 3 June 2012]. 